\title{
Erratum
}

Cold Spring Harb Symp Quant Biol 84 (2019) doi: 10.1101/sqb.2019.84.039644

\section{Erratum: Attenuation of Eukaryotic Protein-Coding Gene Expression via Premature Transcription Termination}

\author{
Deirdre C. Tatomer and Jeremy E. Wilusz
}

The abstract of this article included an extraneous word as a result of a production proofing error upon first publication. The phrase "where which the IntS11 RNA endonuclease cleaves" should have been "where the IntS11 RNA endonuclease cleaves." The publisher apologizes for this error. In the current version of the article, the extraneous word "which" has been removed from the abstract.

doi: $10.1101 /$ sqb.2019.84.039784 


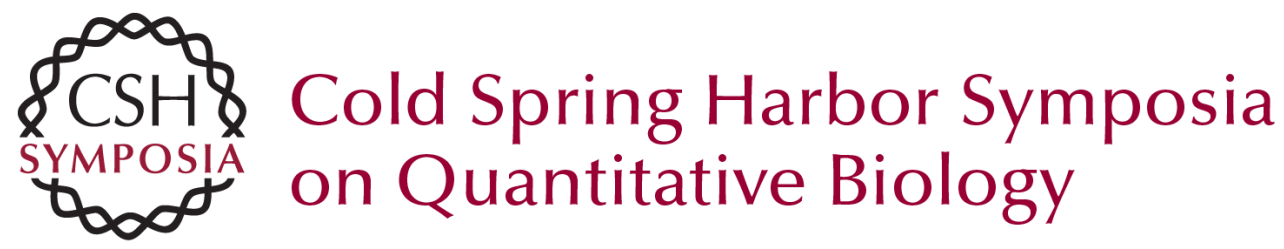

\section{Erratum: Attenuation of Eukaryotic Protein-Coding Gene Expression via Premature Transcription Termination}

Deirdre C. Tatomer and Jeremy E. Wilusz

Cold Spring Harb Symp Quant Biol published online February 27, 2020

Access the most recent version at doi:10.1101/sqb.2019.84.039784

\section{Related Content Attenuation of Eukaryotic Protein-Coding Gene Expression via Premature Transcription Termination Deirdre C. Tatomer and Jeremy E. Wilusz \\ Cold Spring Harb Symp Quant Biol UNKNOWN , 2019 84: 83-93 \\ $\mathbf{P}<\mathbf{P} \quad$ Published online February 27, 2020 in advance of the print journal. \\ License \\ Email Alerting Receive free email alerts when new articles cite this article - sign up in Service the box at the top right corner of the article or click here.}

Advance online articles have been peer reviewed and accepted for publication but have not yet appeared in the paper journal (edited, typeset versions may be posted when available prior to final publication). Advance online articles are citable and establish publication priority; they are indexed by PubMed from initial publication. Citations to Advance online articles must include the digital object identifier (DOIs) and date of initial publication. 